\title{
Between Walras and Ricardo. Ladislaus von Bortkievicz and the origin of neo-ricardian theory
}

Roberto Marchionatti and Raffaella Fiorini

\section{OpenEdition}

\section{Journals}

Electronic version

URL: http://journals.openedition.org/ress/721

DOI: $10.4000 /$ ress.721

ISSN: $1663-4446$

\section{Publisher}

Librairie Droz

\section{Printed version}

Date of publication: 1 February 2000

Number of pages: 173-191

ISBN: 2-600-00409-2

ISSN: 0048-8046

Electronic reference

Roberto Marchionatti and Raffaella Fiorini, « Between Walras and Ricardo. Ladislaus von Bortkievicz and the origin of neo-ricardian theory », Revue européenne des sciences sociales [Online] XXXVIII-117 | 2000, Online since 17 December 2009, connection on 02 May 2019. URL : http:// journals.openedition.org/ress/721; DOI : 10.4000/ress.721 


\section{BETWEEN WALRAS AND RICARDO Ladislaus von Bortkievicz and the origin of neo-ricardian theory}

\section{1. - INTRODUCTION}

Ladislaus von Bortkievicz, «by far the most eminent German statistician since Lexis » (Schumpeter 1932, p. 338), is known in the history of economic theory principally, as Schumpeter wrote, as « one of the most competent critics of Marx and Böhm-Bawerk» (Schumpeter, 1954, p. 851), - but it is also argued that «his essentially critical bent prevented him from producing, so far as economic theory is concerned, any creative work» (ibidem, p. 851), a judgement largely shared by historians until recently: in the New Palgrave Dictionary for example, it is said that «Bortkievicz was essentially a critic» (Meldolesi, 1987, p. 263). Although he undoubtedly had an extraordinarily acute and passionate critical faculty (see Anderson 1931), it is our impression that this preeminent characteristic, which greatly impressed his contemporaries, has led to overlooked his positive theoretical contribution: it lies in an original programme of application of the mathematical method to the Ricardian-Marxian theory of prices; the resulting model had to be conceived, according to Bortkievicz, as a part of the wider setting formed by the Walrasian general equilibrium analysis.

Bortkievicz is also considered to have had a scarce influence at his time - « he could have exerted beneficial influence in Berlin... if he had not stood on a side track, quite overshadowed by Schmoller and Wagner « (Schumpeter 1954, p. 852) - and have been largely ignored by his contemporaries (see for example Kurz 1995, p. 48). Moreover, it is commonly thought that Bortkievicz was rediscovered only at the end of the 1940's by P.M. Sweezy, who interpreted his contribution as a solution of the Marxian problem of transformation of values in prices of production; after that, since the sixties, Bortkievicz's contribution on Marx was considered in the debate on Sraffa's Production of commodities by means of commodities, of which Bortkievicz has been considered to have anticipated some conclusions [Meldolesi (1971), Marchionatti (1981), Howard-King (1998)]. It seems that the available evidence does not confirm the judgement of scarce influence and ignorance of Bortkievicz's contributions. It could be also hypothesized that the characterization of Bortkievicz essentially as a critic - together with the tendency to neglect the intellectual origin of Neo-Ricardian economics from Sraffa's followers - has not helped to thoroughly investigate the positive contribution of the Russian-German scholar and the influence he exerted at his time and on the development of economic theory after.

The aim of this paper is twofold: firstly, to examine closely, on the basis of an existent but dispersed literature, the theoretical and cultural context in which 
Bortkievicz's economic research originated and was developed, in order to show not only some neglected connections but also the important role played by Bortkievicz among continental economists at the beginning of the twentieth century; secondly, to investigate the relationship with Sraffa's model, to show similarities and differences in their research programmes and results.

\section{2. - LADISLAUS VON BORTKIEVICZ, WALRASIAN AND THEORETICIAN OF NEORICARDISM}

\subsection{Bortkievicz in his historical context}

Ladislaus von Bortkievicz was born in 1868 in S. Petersburg, Russia, in a family of Polish origin and studied at the University of St. Petersburg, then at Göttingen, where in 1893 he wrote his doctoral thesis in statistics under W. Lexis ${ }^{1}$, whose Bortkievicz was his «most direct intellectual descendent» (Stigler 1986, p. 236). In the same year Léon Walras, with whom Bortkievicz was corresponding since 1887 and who considered Bortkievicz a qualified advocate of his theory ${ }^{2}$, offered him the chair of political economy at the University of Lausanne as his successor, but Bortkievicz initially refused; and when later he offered his availability Vilfredo Pareto had already been appointed. In 1895 Bortkievicz became Privatdozent in the University of Strasbourg, where he taught insurance and theoretical statistics. In 1898, Walras proposed ex-aequo Maffeo Pantaleoni and Bortkievicz for the chair of political economy at the University of Geneva (see Walras' letter to Bortkievicz of 25 March 1898, in Jaffé 1965, vol. III); but Pantaleoni was preferred. Bortkievicz was also in the list of possible successors to Pareto, but the Italian economist did not consider him an acceptable candidate, describing him as «a half-socialist» (un demi-socialiste) (Letters to Pantaleoni, 31 May 1898, vol. II, pp. 201-2) ${ }^{3}$. Backing Russia Bortkievicz taught in the exclusive Aleksandr Liceo from 1899 to 1901 . Finally in 1901 he became professor of Political Economy and Statistics at the University of Berlin, initially associate professor and then, from 1920, full professor ad personam, where he taught until his death in 1931.

Bortkievicz was, first of all, a follower of mathematical method in economics. The introduction of mathematical reasoning in economics had increasing importance for the economists of that time and represented a crucial change. Between the 1870's and 1890's, the use of mathematical method in political economy was

Lexis was an eminent statistician who wrote extensively on economics. As Keynes (1914) wrote: «Lexis was a worthy member of the band of veteran economists ... who in the seventies and eighties of the last century raised so high a level the reputation of German economic science» (Keynes, 1972, p. 318).

2 Bortkievicz defended Walras from Edgeworth's criticism of the second edition of Eléments published in 1889 (Bortkievicz 1890). When Walras read that note, which was then the review, sent to him by Bortkievicz himself, he wrote to him that he had «a man capable of reading me attentively, understanding me perfectly, and capable of defending my point of view as well as myself, if not better» (letter of the $8^{\text {th }}$ of December, 1889).

3 Probably, in Pareto's un-sympathetic attitude toward his colleague, the critical review of the Cours by Bortkievicz (1898) was not extraneous. 
at the centre of a lively discussion, above all in France, the United Kingdom and Italy, and also marginally in USA. For economists like Walras and Pareto, mathematics was a necessary tool to understand general relationships between variables and to make rigorous deductions through the representation of an economy by systems of simultaneous equations, and the general economic equilibrium was the field of application for mathematics par excellence (see Bouvier 1912, Zawadski 1914, Marchionatti-Gambino 1997). In Germany, where the Historical School was largely dominant, mathematical economics had a very limited diffusion in the seventies and eighties. Likewise in Russia: in his first letter to Walras on 24th October/5th November 1887 (see Jaffé 1965, vol. II) Bortkievicz, at that time a young student deeply interested in economics, wrote that unlike the rest of Europe, where there was a certain number of scholars in mathematical economics, in Russia the predominant importance of the Historical School had, until then, prevented the diffusion of mathematical method and economic theory itself. Nevertheless, Bortkievicz believed that reaction to that school be inevitable in Russia as well. In the gradual establishment of a mathematical school in Russia, from the point of view of the method used, Walras was the essential reference. The peculiarity of the work of our author, however, is that in his examination of the theories of prices he used a 'classical' approach. This insistent reference to the classical economists is not surprising: classical legacy was well alive in these countries. In Russia, Ricardo's theory had been made available since the seventies by N. I. Ziber, professor of Political Economy and Statistics at the University of Kiev, an important figure in the Russian cultural panorama (see Scazzieri 1987): Ziber considered Marx's theory a 'necessary' sequel to the teachings of Smith and Ricardo. With regard to Marx, as Schumpeter says:

\footnotetext{
Scientific work done on Marxist lines ... was until about 1930 so largely confined to German and Russian writers ... It was in Germany and Russia only that Marxism exerted a strong influence upon the work of non-socialist economists: for a time, theory-minded economists had in these countries hardly any choice but to turn to Marx ... and Rodbertus ... The relation between Russian and German Marxists remained very close (Schumpeter 1954: 878).
}

In Russia, Das Kapital received a generally favourable reception from the publication of the first Book, as Marx himself recognized in his 1873 postface, and by the 1890's, interest in Marx became relevant in Germany as well (see Marchionatti 1998). Since then, discussion of a possible synthesis of marginalist and classical political economy has not been uncommon, in particular by Michail Tugan Baranowski (see Nove 1987 and Timoshenko 1954), for a long period privatdozent and then professor of Political Economy at the University of St. Petersburg, whose books, especially Theoretische grundlagen des Marxismus, published in 1905, exerted a wide influence on the Marxist discussion in Russia and Germany. It is a discussion that also involved Bortkievicz and another Russian mathematical economist of whom Bortkievicz adopted the algebraic method in his 1906-7 paper: Vladimir Karpovich Dmitriev, who, in the title page of the 1902 and 1904 editions of his Economic Essays on Value, Competition and Utility, promised an «organic synthesis of the labour theory of value and the theory of marginal utility». 
Actually between the second half of the 1890's and the end of the 1920's a group of Russian and German scholars set up an original programme of research characterized by the application of mathematical method to the theory of prices in a classical political economy framework. Ex post they probably deserve the name of Russian-German mathematical «school» of political economy, although they only partly worked as a real school (see Gilibert 1990). In addition to Bortkievicz the members of this «school» may be considered: the already quoted Vladimir K. Dmitriev (1868-1913), the first Russian mathematical economist, a figure then forgotten in the history of economic thought and only rediscovered at the end of sixties (see Shaposhnikov 1914, Nuti 1973, Gehrke 1998), the German mathematician Robert Remak (1888 - Auschwitz 1943?) (see Wittman 1967), the Russian born economist Wassily Leontiev (born 1906-1999), then a Nobel laureate in economics, and the Russian mathematician emigrated to Germany for political reasons Georg von Charasoff (1877-?), who was the only «Marxist» of this group of scholars and, as far as we know, worked principally on his own (see Egidi-Gilibert 1984 and Egidi 1998).

The use of mathematical method was the first element unifying these scholars. The peculiarity of the works of our authors, however, as we said above, is that in their examination of the theories of prices they always used a 'classical' approach, whether the subject of their inquiry was the defence and mathematical reformulation of Ricardo's and Marx's classical theory of prices against the criticism of Walras (on Ricardo) and Böhm-Bawerk and his followers (on Marx), or the issue of the rational system of prices in a centrally-planned economy, and the basic structure of that economy whatever its social and institutional features.

Ladislaus von Bortkievicz may be considered the leading figure of the Russian-German mathematical school of political economy. This role was probably also due to the fact that he was at the University of Berlin, one of the most important universities of Central Europe and, at the beginning of 1900, a very important centre of mathematical studies in Germany (see Begehr et al. 1998). Although an effective group of followers was never formed in Germany, Bortkievicz's house in Berlin, as the Swedish statistician Oskar Anderson remembers (1932), was for decades a place of pilgrimage, where scholars from different countries gathered to discuss problems and seek advice. Also many young Italian students of economics went to Berlin to attend Bortkievicz's lessons and seminars. This was testified by Vilfredo Pareto who, in a letter to Pantaleoni $\left(13^{\text {th }}\right.$ October 1907), complained of that. Among the students who studied in Berlin with Bortkievicz there are two of the economists above quoted: Wassily Leontiev and Robert Remak. Leontiev, after obtaining a degree in economics at the University of St. Petersburg in 1925, went to the University of Berlin to continue his studies with Sombart and Bortkievicz. There in 1928 he obtained his Ph.D. with a dissertation entitled «Wirtschaft als Kreislauf», in which, from a criticism of the separation between technology and economy as a necessary precondition for economic theorizing, he presented the economy as a system of circular economic interrelationships based on an objective technological framework. Leontiev (1991) recalls that the text, submitted in the Autumn of 1927 to the Dean of the University of Berlin with his application for a Ph.D. degree, was accompanied by Bortkievicz's confidential appraisal: 
Although I find much that is objectionable in it, this dissertation is without any doubt acceptable. In developing his - in my opinion very doubtful - theoretical constructs the candidate received no guidance whatsoever from his academic teachers. He arrived at his present position quite independently, one might say, despite them. It is very likely that he will maintain this scientific point of view also in the future (p. 179).

Robert Remak was a student of the eminent mathematicians Georg Frobenius and H. A. Schwarz, from whom he received his doctorate in 1911: he was Privatdozent at the University of Berlin from 1929 to 1933, more or less the same period in which Von Neumann was there [1927 to 1929 (see Ulam 1958)]. In 1929, probably following Bortkievicz's suggestions, Remak carried out a study on the determination of rational prices for a centrally planned closed economy (Remak 1933). This was probably a problem which Bortkievicz had found interesting since the end of the 1880 s (see the letter to Walras of the $23^{\text {rd }}$ November 1887). The contemporary presence in Berlin of Von Neumann and Remak gave rise to the conjecture, advanced by Wittman (1967) and revived by Kurz and Salvadori (1993) and also accepted by Leonard (1995), that in preparing his model, the young Von Neumann had in mind the model his older colleague had presented at a Berlin Mathematical Society seminar, which had been discussed and hardly criticized inside Berlin's Mathematical Institute ${ }^{4}$. This points out the existence of a probable connection between the Russian-German school and the reformulation of general economic equilibrium theory developed in the Thirties in Vienna. In any case the death of Bortkievicz in 1931 and then the tragic events in Germany and Austria when Nazism came to power, these theoretical contributions were broken off: they would have been resumed in United Kingdom and in United States; but in the new contexts the connection with Bortkievicz and the Russian-German school seemed to be, with the probably partial exception of the Sraffa's case, irremediably lost.

\subsection{Bortkievicz's Neo-Ricardian contribution}

In economics, Bortkievicz was principally a follower of Walras. He considered the French economist, as he once wrote to him, his «master in pure political economy» from whom, he said, «I accepted the theoretical system to the extent that it is inherent in my way of conceiving the economic world» (letter of 13 September 1891, in Jaffé 1965 vol. II, p. 463). His interest in Ricardo and Marx was, according to himself, not inconsistent with his Walrasianism: as already said, he maintained that general equilibrium analysis was the wider setting within which to insert cost equations determined in the Ricardian model. This model, elaborated in his 1906-7 article, written when he was at the University of Berlin, represents Bortkievicz's most important achievement.

\subsubsection{The Marxian issue of transformation in Bortkievicz's analysis}

In his article Bortkievicz examined the Marxian issue of the transformation of values into prices of production, an issue which the third volume of Das Kapital,

Whether the conjecture is valid or not, undoubtedly the two models share an important peculiarity: the search for economically significant solutions to the equation system, at that time a key issue in the discussion on general economic equilibrium. 
published in 1894, had set at the centre of an important debate. Bortkievicz reviewed several criticisms of Marx and in his assessment of the problem adopted Lexis' reviews of the second and third Book of Das Kapital (1885 and 1895) as his methodological starting point. Lexis considered Marx a Ricardian and related Marx's ideas to those of Ricardo and Quesnay: Marx resembled Ricardo «in method and in cast of mind», and Ricardo supplied Marx with the point of departure for a system which could essentially be considered a development of Ricardo. With regard to the transformation of value into prices of production, he thought Marx's solution «simple and obvious» and showed that there was no fixed relation between the value and the actual prices of commodities. He maintained that value is a purely theoretical construct - rejecting Engels' idea of a historical dimension to the transformation problem -, an «imaginary and unreal conception of value» but «a convenient introduction» to the analysis of capitalistic production $^{5}$. Bortkievicz conceived his work as an integration of Lexis' criticism and a complete examination of the mathematical transformation of value into prices of production. His aim was to elaborate a scientifically effective answer to BöhmBawerk's challenge to the Marxists : in 1896 Böhm-Bawerk had published a criticism of Marx which had a considerable impact on the economic profession. In the final part of this essay, turning his attention to Sombart on Marx, and admitting the difference between objective and subjective investigative methods that separated himself from Marx, Böhm-Bawerk claimed to be criticizing Marx not on his choice of method but for «his mistakes in the application of his chosen method», thus implicitly launching a challenge to the Marxist to show that an objective theory of prices was possible. In order to do this, Bortkievicz had to formulate a logically consistent objective theory of prices.

Bortkievicz's model offered a solution to the price problem from the neo-Ricardian perspective begun by Dmitriev, whose algebraic method (from his work on Ricardo) Bortkievicz adopted. In his first essay «The theory of value of D. Ricardo » (1898) Dmitriev rejected Walras' criticism of Ricardo: Walras had accused Ricardo of trying to make 'one equation determine two unknowns' by suggesting that price is determined by the cost of production, consisting of profit plus wages and profit determined as the difference between aggregate prices and wages. Using the mathematical method, Dmitriev was the first to rigorously demonstrate that Ricardo's theory was immune to Walras' criticism; he was also the first to define the mathematical core of classical thought on value and to define Ricardo's inquiry as dominated by his theory of profit - a thesis then sustained by Bortkievicz and later by Sraffa in his introduction to Ricardo's Works and Correspondence (1951).

\subsubsection{The model}

Dmitriev and Bortkievicz had different purposes in writing their essays: the aim of Dmitriev was the defense of Ricardo's theory of value from Walras' accu-

\footnotetext{
Lexis' interpretation of value as a purely theoretical concept was sustained by two other German reviewers of the third volume of Das Kapital: Werner Sombart (1894) and Conrad Schmidt (1895), a young Marxist later to become an important exponent of revisionism. From an epistemological point of view, the Lexis-Sombart-Schmidt thesis that value is a fiction constituted a break in the debate on the Marxist theory of value (see Marchionatti 1998).
} 
sation of circular reasoning, while Bortkievicz intended to solve the Marxian problem of the transformation of values into prices of production. Nevertheless, their mathematical models of price theory are formally the same. We may, therefore, refer to a unique «Dmitriev-Bortkievicz model», whose basic assumptions are known technology of production, constant returns to scale, no rent and single production ( $n$ commodities produced by $n$ industries).

In the equations below, we use the following notation:

- $y_{i}=$ Commodities prices $(\mathrm{i}=1, \ldots, \mathrm{n})$

$-\rho=$ Rate of profit

$-a_{j}=$ Technical coefficients of production $(\mathrm{j}=1, \ldots, \mathrm{m}) ; A=\sum^{\mathrm{m}}{ }_{j=1} a_{j}$

- $\lambda=$ Unit cost of, in Sraffa's terminology, the 'basic commodity': for Dmitriev and Bortkievicz, as well as Ricardo and Marx before then, «basic commodity » being the human labor ${ }^{6}, \lambda$ is the real wage

- $\Lambda=$ Total cost of the «basic commodity $(\Lambda=A \lambda)$

$-t_{i 1}, t_{i 2}, \ldots, t_{i m}=$ Turnover periods with regard to production and distribution of wage-commodities $(\mathrm{i}=1, \ldots, \mathrm{n})$. We assume they are different, such that $t_{i 1}<t_{i 2}<, \ldots,<t_{i m}(\mathrm{i}=1, \ldots, \mathrm{n})$, and assuming that the total costs of each commodity are distributed in the $m$ turnover periods $t_{i 1}<t_{i 2}<, \ldots,<t_{i m}$, that is expenses are $\lambda a_{i 1}, \lambda a_{i 2}, \ldots, \lambda a_{i m}$ in $t_{i 1}<t_{i 2}<, \ldots,<t_{i m}$. We write the following system of $n$ equations for $(n+2)$ unknowns, $y_{i} \rho, \lambda$

(i) $y_{i}=(1+\rho)^{t}{ }^{1} \lambda a_{i 1}+(1+\rho)^{t} i_{2}\left(a_{i 2}+\ldots+(1+\rho)^{t} i m \lambda a_{i m}(\mathrm{i}=1, \ldots, \mathrm{n})\right.$

6 Following the classical economists, Dmitriev and Bortkievicz considered human labour as a basic commodity but were also aware that it was possible to remove this restriction, thus extending their conclusions to any basic commodities. Dmitriev (1904) wrote: «the starting point for Ricardo's analysis was provided by the present-day capitalist system based on the use of hired human labour; it would, however, be extremely erroneous to imagine that the conclusions at which he arrived have a bearing only on the present time» (p. 61). Therefore they tried to demonstrate (not always correctly, as Garegnani 1960 noted) that their expressions are valid in a set of cases: a) with regard to the quantity of basic commodity employed, with one basic commodity only or with a basket of basic commodities in fixed proportions; b) with regard to the type of basic commodity employed, with only current labour (Marx's 'variable capital') or circulating and fixed capital; c) finally, with regard to the time of utilization, with a basic commodity totally anticipated or entering the product price bit by bit. Dmitriev concluded: «We have therefore seen, proceeding from Ricardo's analysis, that the origin of industrial profit does not stand in any 'special' relationship to other production processes provided that they satisfy the quite definite conditions stated above » (p. 64). Bortkievicz (1907) maintained: «Equation ( i ) thus proves to be the general expression for the price of a commodity. This is so independently of the circumstance whether, and to what degree, the production of this commodity has required not only variable capital, but also the use of constant capital, either circulating or fixed. This theorem ... agrees essentially with Ricardo's theorem that all differences between commodities with regard to the greater or smaller contribution made by fixed capital in their production, can be traced back to differences in the length of their period of production» (p. 253). Thus, according to both Dmitriev and Bortkievicz, the model is not only a model of 'production of commodities by means of dated labour', as it appears at first glance, but a more general model of 'production of commodities given an initial condition', a commodity or any other type of energy (human labour or otherwise). 
which define the general relation between commodity prices and production costs, using the same commodity unit. To find a solution we must add:

1. the price equation of the commodity which serves as a measure

$$
1=(1+\rho)^{t_{\mathrm{n}+1,1}} \lambda a_{n+1,1}+(1+\rho)^{t_{\mathrm{n}+1,2}} \lambda a_{n+1,2}+\ldots(1+\rho)^{t_{\mathrm{n}+1, m}} \lambda a_{n+1, m}(\mathbf{n}+\mathbf{1})
$$

2. the price equation of the «basic commodity» used in the production of the good, that is its production cost

$$
\begin{aligned}
& \left(=(1+\rho)^{t_{\mathrm{n}+2,1}} \lambda a_{n+2,1}+(1+\rho)^{t_{\mathrm{n}+2,2}} \lambda a_{n+2,2}+\ldots(1+\rho)^{t_{\mathrm{n}+2, \mathrm{~m}}} \lambda a_{n+2, m}\right. \\
& \text { that is, } 1=(1+\rho)^{t_{\mathrm{n}+2,1}} a_{n+2,1}+(1+\rho)^{t_{\mathrm{n}+2,2}} a_{n+2,2}+\ldots(1+\rho)^{t_{\mathrm{n}+2, \mathrm{~m}}} a_{n+2, m}(\mathbf{n}+\mathbf{2})
\end{aligned}
$$

Thus, we can calculate the rate of profit ( as a function of technical productive conditions of the «basic commodity»

$$
\rho=f_{\lambda}\left(a_{n+2, j}, t_{n+2, j}\right)
$$

and, substituting the value of ( into the equation $(\mathbf{n}+\mathbf{1})$, we can obtain the value of $\lambda$, and therefore the commodity prices $y_{i}(\mathrm{i}=1, \ldots, \mathrm{n})^{7}$.

We should note that in the Dmitriev-Bortkievicz model, the price of commodities is shown independent of the wage-rate. A change in the rate of profit does not cause any change of prices in the same direction, either: the rate of profit «depends only on those amounts of labor and those turnover periods which concern the production and distribution of the goods forming the real wage-rate » (p. 263).

Finally, from the equation $(\mathbf{n}+\mathbf{2})$ from which $(\mathbf{I})$ is obtained, it is easy to demonstrate that:

1. the turnover periods $\mathrm{t}_{n+2, j}(\mathrm{j}=1, \ldots, \mathrm{m})$ being finite values, the condition $\mathrm{A}_{n+2}=\sum_{j=1}^{\mathrm{m}} a_{n+2, j}<1$ implies $\rho>0$;

2. the function $f_{\lambda}$ is decreasing both in $a_{n+2, j}$ and in $t_{n+2, j}$ : this means that the rate of profit is smaller the greater the quantity of labor necessary to produce the commodity, if the turnover periods are equal, or the greater the time passing from the moment in which the labor is employed until the moment in which the finished good is produced, if the quantity of labor employed is equal.

According to many historians, what separates Bortkievicz in a distinct way from his predecessors is that he demonstrated, clearly and unequivocally, that value is not an autonomous concept, but simply a particular case of the theory of prices. His proof consisted in certain successive steps. Firstly, he clarified the significance of the concept of «value» (relative and absolute) and «price of production» (in brief, the price «which is essentially the same as natural price of classical economists »). Absolute value is the «quantity of labor employed in its [the commodity] production» (Bortkievicz 1907, p.239), whilst relative value is «merely the index of an exchange relationship; ... a firm quantitative relationship nevertheless prevails between them: the values of different goods bear the same proportion to each other as their absolute values » (ib. p. 238), and price is, «like value, the index (or exponent) of an exchange relationship and again, just like value, represents a purely theoretical structure, although price, i.e. price of production, ... represents a higher degree of approximation to reality than does value ... Price calculation means to determine the same exchange-relationship according to the law of the equal rate of profit» (ib. p. 239) 


\section{3. - BORTKIEVICZ AND SRAFFA}

Piero Sraffa's 1960 book, Production of Commodities by Means of Commodities, represented a major event in economic science in the sixties and confirmed his reputation as a great economist of the Twentieth century: not by chance an outstanding mainstream theoretician like Paul Samuelson spoke of «this age of Leontiev and Sraffa» (Samuelson 1971, p. 400) and defined Sraffa's book a classic. However the significance of the book, in the absence of any explanation of its genesis by Sraffa himself, has been a matter of extensive debate in which the disagreement has prevailed ${ }^{8}$. During the last few decades some scholars (see Nuti 1974, Marchionatti 1981, Gilibert 1990, Samuelson 1991) have emphasized the existence of an interesting theoretical connection between Sraffa's approach in Production of Commodities and the works of the Russian-German mathematical economists from the beginning of the century - principally Bortkievicz and Dmitriev. A systematic analysis of this relationship has however been lacking.

In Sraffa's unpublished papers at Wren Library, Trinity College, Cambridge, a notebook on Bortkievicz is kept, but it was written in the forties, a time by which the « central propositions » of Production of Commodities by means of Commodities had already been completed. Sraffa himself informs us, in the preface to Production of Commodities, that «the central propositions had taken shape in the late 1920 's », whereas other particular points «such as the standard commodity, joint products and fixed capital, were worked out in the thirties and early forties » (p. v) ${ }^{9}$. On the basis of the available evidence it is not possible to suggest that Sraffa could have taken Bortkievicz or Dmitriev as a starting point for his work or found the idea for his book in their works: no such evidence exists anywhere in Sraffa's published and unpublished papers. Of course, it is possible that Sraffa, in his Italian years, had some knowledge of Dmitriev and Bortkievicz, since they were known in the intellectual circles of Italian economists at the beginning of the century - as cited above, Pantaleoni and Pareto on Bortkieivcz; moreover Achille Loria quoted Dmitriev in Loria (1922) and was quoted by Dmitriev (see Bellanca 1997) -, but Sraffa could likewise have elaborated his theoretical position quite

8 In his important commentary on the book, Newman (1962) pointed out that some of the first reviewers had considered it a great theoretical advance, while others had judged it as just another Leontief-type model, original only from its subjective point of view. Newman ascribed these differences of opinion to the extreme difficulty of the work: «compressed and mathematically incomplete as it is, the main trouble lies not there, but in wrenching oneself out of the more usual Walrasian approach to general equilibrium, and in substituting a Ricardian viewpoint» (p. 58). Actually, in the following years, many scholars tried to show that Sraffa's work represented the rehabilitation of the classical objective theory of value and distribution against marginalist subjectivism, and the demonstration that the Ricardo-Marx approach was logically consistent (see, for example, Steedman 1977, Roncaglia 1978, Garegnani 1984, Eatwell-Panico 1987). Different and opposing judgements, however, were not absent, as is evident in the perspectives of Napoleoni (1976) and Samuelson (1987).

9 On the basis of Sraffa's unpublished papers, it is possible to say that the first draft of the system of equations shown by Sraffa to the Cambridge mathematician Frank Ramsey at the end of 1927, in order to discuss a solution with him, is quite rough in comparison with the final version of the part of Production of commodities by means of commodities we discuss here; which was sketched by Sraffa in the following years. 
autonomously. The appearance (or reappearance) of similar theoretical positions in different places independently, is certainly not unusual in the history of ideas. In any case the evolution of Sraffa's thought - which, we could say, represents an uninterrupted dialogue with the classical economists in the elaboration of an antimarginalist programme - appears so original that the question of the historical relationship between him and the Russian-German school does not seem so relevant from a theoretical point of view. Instead, what is theoretically relevant are the close similarities in the interpretation of classical economists and the analytical translation of their vision of economic process. The following pages deal with the theoretical relationship between Sraffa's central proposition and the BortkieviczDmitriev model presented above.

\subsection{Sraffa's Production of Commodities by means of Commodities «central propositions»}

We consider the first two and a part of the sixth chapters of Sraffa's book, which contain his central model ${ }^{10}$. It represents an economic system where there are $n$ industries, $n$ commodities and $n \times n$ relations between them (known as «methods of production»). The basic assumption of the model are: the process of production is circular (that is the products are also the means of production and

10 We adopt Sraffa's mathematical language and demonstrative techniques. It is common opinion that Sraffa's analysis is, from a mathematical point of view, incomplete and unsatisfying: a) the hypotheses are not listed in order and are often to be extracted from footnotes, the use of the axiomatic method does not appear explicitly, theorems used are implicit; b) the algebra is elementary. Sraffa's use of it seems to be - unlike Bortkievicz, for whom algebra was a scientific achievement compared to the previous arithmetical techniques used - a device in order to make the notation adopted «easy to follow for the non-mathematical reader», explicitly admitting that he did not always follow «the expert advise» given to him from mathematicians like A.S. Besicovich, F. Ramsey and A. Watson; c) Sraffa, like Dmitriev and Bortkievicz, did not dealt with the problem of the existence of an economic, not only mathematical, solution to his system of equation, but simply used the method of « counting equations and unknows».

With regards to the first point, it should be noted that, as shown in our exposition of Sraffa's model, the hypotheses, the theorems used and the axioms can be made explicit without difficulties. As regards the second point, the propositions of the book can be translated in the language of matrix algebra. After the publication of Sraffa's book, economists and mathematicians, actually, tried to do it, using topological structures and the linear operator theory. But why did Sraffa himself not use these techniques extensively, which he certainly knew ? A reason for this may be found, as Dore (1989) maintains, in the fact that the consequences of the utilisation of matrix algebra is the implicit introduction of the hypothesis of the constant return of scale, as matrices are definable up to a multiplicative constant. With regards to the third and final point, at a first glance it seems that Sraffa referred to a preaxiomatic mathematical tradition typical of the nineteenth century. As a matter of fact, it seems more plausible to think that Sraffa's mathematical notation is the result of a carefully considered choice, «although admittedly open to objection in some respect » (Sraffa 1960, p. vii). Sraffa, in contrast to the convention among mathematicians of reducing explanations to a minimum and stating assumptions as concisely as possible, preferred to give examples and descriptions of his argument, in order not only to ease the reader's task of comprehension but also to maintain some references to empirical economic processes. In other words, Sraffa's object might have been to show that the language of rigor in economics does not necessarily imply the adoption of a language reduced to a manipulation of symbolic strings. In this manner, he could manifest his criticism of Hilbertian mathematical formalism in economics as adopted by the Viennese theoreticians of the General Economic Equilibrium. 
there are no other means of production apart from the products); the total quantities of each product and the production technology are given; commodities are divided into basic and non-basic and the system contains at least one basic commodity - a basic commodity enter directly or indirectly into the production of any other commodities -; the wage is variable and paid post-factum as a share of the annual product.

We can write the following system of $n$ equations for $(n+2)$ unknowns, $y_{i}, r, w$ : $\left(a_{i 1} y_{1}+a_{i 2} y_{2}+\ldots+a_{i n} y_{n}\right)(1+r)+\mathrm{L}_{i} w=\mathrm{A}_{i} y_{i}(\mathrm{i}=1, \ldots, \mathrm{n})($ II $)$ with the following constraints

$$
\begin{aligned}
& \sum_{i=1}^{\mathrm{n}} a_{i j} \leq A_{j}(\mathrm{j}=1, \ldots, \mathrm{n}) \\
& \sum^{\mathrm{n}}{ }_{i=1} L_{i}=1
\end{aligned}
$$

where:

- $A_{i}(\mathrm{i}=1, \ldots, \mathrm{n})=$ quantities of commodities annually produced $\left(A_{i}>0\right)$

- $a_{i j}(\mathrm{i}, \mathrm{j}=1, \ldots, \mathrm{n})=$ technical coefficients of production

(that is the quantity of commodity $i$ used by the industry $j$ to produce a unit of commodity $j$, which can be positive or zero)

- $w$ and $r$ are respectively the wage-rate and the rate of profits

To solve the system (II), Sraffa, instead of arbitrarily choosing a single commodity in terms of which the other prices may be expressed, assumes as a standard a «composite commodity» that is the set of commodities of which the national income is composed: the value of this commodity is set up to unity. We have therefore the additional equation

$$
\left(A_{1}-\sum_{j=1}^{\mathrm{n}} a_{1 j}\right) y_{1}+\left(A_{2}-\sum_{j=1}^{\mathrm{n}} a_{2 j}\right) y_{2}+\ldots+\left(A_{n}-\sum_{j=1}^{\mathrm{n}} a_{n j}\right) y_{\mathrm{n}}=1
$$

and the system becomes of $(n+1)$ equations with $(n+2)$ unknowns, $y_{i}, w$ and

$$
r=\frac{1}{\sum_{i=1}^{n} a_{i j} y_{i}}
$$

This system has one degree of freedom: in order to solve the system of equations, one of the two distributive variables - wage or rate of profits - has to be fixed.

In the sixth chapter of his book, Sraffa presents «the reduction to dated quantity of labour» by which prices are considered «from their cost of production aspect, and the way in which they resolve themselves into wages and profits » (Sraffa 1960, p. 34). Taking the equation which represents the production of a certain quantity of a commodity $A_{i}$

$$
A_{i} y_{i}=\mathrm{L}_{i} w+(1+r) \sum_{j=1}^{\mathrm{n}} a_{i j} y_{j}
$$

Sraffa points out that $(1+r) \sum_{j=1}^{\mathrm{n}} a_{i j} y_{j}$, i.e. the value of the means of production used to produce $A_{i}$, is itself a commodity, produced a year earlier and multi- 
plied by a profit factor $(1+r)$ at a compound rate for the appropriate period; thus it can be replaced with its means of production and the quantities of labour employed in its production. This procedure can be repeated, backwards through the years, replacing the means of production with their own means of production and quantities of labour, and applying to the formula a profit factor for the appropriate period. In the end, we obtain the following «reduction equation» for the product $i$, « in the form of an infinite series » (ibid. p. 35):

$$
A_{i} y_{i}=\mathrm{L}_{i} w+\mathrm{L}_{i 1} w(1+r)+\mathrm{L}_{i 2} w(1+r)^{2}+\ldots+\mathrm{L}_{i n} w(1+r)^{\mathrm{n}}+\ldots
$$

where $\mathrm{L}_{i j}(\mathrm{j}=0,1, \ldots, \mathrm{n})$ are the quantities of labour employed in the production of the commodity $i$ in the year $t-j, t$ being the current year. The general term of the series is $\mathrm{L}_{i n} w(1+r)^{\mathrm{n}}$ in which the quantities of labour are «dated», i.e. a different weight is applied to them depending on the time of utilization, $w(1+r)^{\mathrm{n}}$. In this way, the price is resolved into wages and profits, but not totally because «beside the labour terms there will always be a 'commodity residue' consisting of minute fractions of every basic product» (ibid. p. 35) $)^{11}$.

Let us go back to system (II). If we let $w$ be an independent variable which move from zero to 1 , we have three remarkable cases:

1. $w=1$

The whole national income is resolved into wages and $r=0$ : the system is in a strict self-replacing state. Sraffa emphasizes that this is the only case in which the classic theory of labour-value is valid.

2. $w=0$

The whole national income is resolved into profits, and the rate of profits is at its maximum $(R)$; it should be noted that this is equal to the proportion between the value of net product and the value of the means of production not only in the whole system but also in each industry. Moreover, in this case, in the equations of model ( II ), commodity prices are proportional to the quantity of capital used to produce them: we have what may be called a capitalvalue theory.

3. $0<w<1,0<r<1$

We have two cases, depending on the technology of production:

a) Labour and means of production are used in the same proportions in the different industries. In this case there is an inverse proportion between rate of profits and wage so that a change in the rate of profits is reflected by proportional, but in an inverse direction, changes in the wage rate: there are therefore no changes in the price system;

b) Labour and means of production are employed in different proportions in the various industries (this is the general case). In such circumstances, prices will change.

11 Nevertheless you can always «by carrying the reduction sufficiently far, to render the residue so small to have, at any prefixed rate of profit short of $\mathrm{R},(\mathrm{R}$ is the maximum rate of profits n.d.a.) a negligible effect on price. It is only at $r=R$ that the residue becomes all-important as the sole determinant of the price of the product» (ibid. p. 35). 
In case $b$, the relationship between wage and rate of profits becomes more complex, although one continues to be a not increasing function of the other. To analyze the effects of wage changes on the commodity prices it is necessary to solve a priori the problem of isolating the price-movements, so that they may be observed as in a vacuum. In other words, a commodity must be found (or created ad hoc) for use as an absolute measure of value: the standard commodity. Analysis of standard commodity as well as joint production is not considered here, since these do not belong to the «central propositions». Nevertheless, it should be emphasised that with the standard commodity Sraffa is able to demonstrate the convergence of the series of reduction to dated quantities of labour which leads to some crucial consequences for his analysis:

- firstly, the impossibility of defining the determining factors of prices: in fact, unvarying the methods of production and varying the rate of profits, a permanent change in the price system emerges (which also means the price system is not stable), and price-movements cannot be reconciled with any conception of price-determination independent of distribution.

- secondly, the criticism and refusal of the old neo-classical idea (of Wicksell and Böhm-Bawerk) of capital (conceived as an aggregate of means of production) as a measurable quantity independent of distribution and prices. Actually, the term of the series in position $n$ reaches its maximum at a value of the rate of profits depending on $n$, i.e. on the stage of production: this fact explains the complexity of the relation between rate of profits and commodity prices. Thus, according to Sraffa,

The reversal in the direction of the movement of relative prices, in the face of unchanged methods of production, cannot be reconciled with any notion of capital as a measurable quantity independent of distribution and prices. (Ibid.)

\subsection{A Comparison between the models of Sraffa and Dmitriev-Bortkievicz}

Dmitriev-Bortkievicz model makes three assumptions - given technology, constant returns of scale and no rent - but only the first one is mandatory, in order to guarantee the same number of equations and unknowns and thus the existence of a solution of the equations system ${ }^{12}$. Now let us compare the two models:

- Sraffa's system of single-product production with surplus

$$
A_{i} y_{i}=\left(a_{i 1} y_{1}+a_{i 2} y_{2}+\ldots+a_{i n} y_{n}\right)(1+r)+a_{i 0} w(\mathrm{i}=1, \ldots, \mathrm{n})
$$

12 The hypothesis of no rent was introduced by Dmitriev for two reasons:

a) to make the price a function of only two factors (wage and profit) instead of three (wage, rent and profit), as Smith thought;

b) to guarantee a uniform rate of profit in the various industries possible: in fact, the absence of rent means that all the capital units employed in the production are productive in the same way and, as a consequence, the analysis becomes easier, profit being now only a function of the capital employed and turnover periods.

Bortkievicz demonstrated that you could replace the no rent hypothesis with a uniform rate of profits without any impact on results. 
- and the Dmitriev-Bortkievicz model

$$
y_{i}=(1+\mathrm{r})^{t} \mathrm{i} 1 w a_{i 1}+(1+\mathrm{r})^{t} \mathrm{i} 2 w a_{i 2}+\ldots+(1+\mathrm{r})^{t} \mathrm{i} \mathrm{n} w a_{i n}(\mathrm{i}=1, \ldots, \mathrm{n})
$$

For reasons of comparison, some modification of the original assumptions has to be made. In particular, in Sraffa's model we must:

- $\quad$ normalize output $A_{i}$, i.e. $\operatorname{set} A_{i}=1(\mathrm{i}=1, \ldots, \mathrm{n})$

- assume the wage anticipated at the beginning of the period of production (the classical hypothesis).

Thus, Sraffa's model becomes:

$$
y_{i}=(1+r)\left(a_{i 1} y_{1}+a_{i 2} y_{2}+\ldots+a_{i n} y_{n}+a_{i 0} w\right)(\mathrm{i}=1, \ldots, \mathrm{n})
$$

At this point, we may follow two different procedures, depending on the results we wish to obtain:

- If we want to reduce the commodity prices to one, as the old classical economists used to do with the labour commodity, we have to « reduce» Sraffa's system, after the introduction of the aforementioned assumptions, to dated quantities of labour. The modified model is:

$$
y_{i}=(1+r) w a_{i 1}+(1+r)^{2} w a_{i 2}+\ldots+(1+\mathrm{r})^{n} w a_{i n}+\ldots
$$

This is the same as the Dmitriev-Bortkievicz model, where $t_{i, j}=j(\mathrm{j}=1, \ldots, \mathrm{n})$.

The only difference is that in Sraffa's system, in addition to the terms which represent quantities of labour, there is a "'commodity residue' consisting of minute fractions of every basic product» which, however, «by carrying the reduction sufficiently far» (Sraffa 1960, p. 35), can become «so small as to have, at any prefixed rate of profits short of $\mathrm{R}$, a negligible effect on price» (ibid.).

- If we want to generalize to any basic commodities, we have to change the variables and assume the turnover periods $t_{1}=t_{2}=\ldots t_{n}=1$ in the DmitrievBortkievicz model. In this way, we obtain the modified model:

$$
y_{i}=(1+r)\left(a_{i 1} y_{1}+a_{i 2} y_{2}+\ldots+a_{i n} y_{n}+a_{i 0} w\right)(\mathrm{i}=1, \ldots, \mathrm{n})
$$

In both ways we have shown that the two models may be reduced, from the mathematical point of view, to a single model, which we may call the "Neo-Ricardian model'. We should emphasize however that, taking into account more or less the same system of equations, the procedures adopted to solve it by Dmitriev and Bortkievicz, on one hand, and by Sraffa, on the other, were different. In fact, Sraffa abandoned the classical way of arbitrarily choosing a commodity as a standard, for example setting $y_{n}=1$, to reduce the unknowns from $(n+2)$ to $(n+1)$, and introduced an additional equation (the set of commodities, or composite commodity, which forms the national income, made equal to unity) to increase the total number of equations. 


\subsection{On the differences between Sraffa and Bortkievicz}

The fundamental difference between Bortkievicz (and Dmitriev) and Sraffa lies in the different aim of their research programme: the Italian economist's one was not simply to prove the logical consistency of the classical approach, but rather to demonstrate that it could be a general theory, alternative to marginal theory ${ }^{13}$. From this point of view, the hypothesis of returns of scale was crucial. Sraffa adopted a very different position from Dmitriev and Bortkievicz, who, in their models assumed constant returns of scale. A key achievement of Sraffa's criticism of the Marshall theory of value in 1925 and 1926 was to re-evaluate the classical approach of normal value under perfect competition: he explained the inadequacies of the Marshallian treatment of variable costs and the difficulties of co-ordinating the laws of returns under competitive conditions in a partial equilibrium context and maintained that a foundation of the theory of normal value had to refer to the classical approach that assumed the invariability of costs. Sraffa argued that «only the case of constant returns was generally consistent with the premises of economic theory» (p. vi). A few years later, however, in 1928, he came to the theoretical conclusion that the assumption of constant returns was not necessary in order to determine prices in a classical theoretical context, as is shown in a draft of the opening propositions of Production of commodities read by Keynes. The significant implication of making no assumptions on the nature of returns - that is, separating the issue of price determination from the problem of quantity determination - was that the marginal method could be totally abandoned:

without change either in the scale of an industry or in the "proportions of the factors of production' there can be neither marginal product nor marginal cost (Sraffa 1960, p. v).

On the basis of his new theoretical assumption regarding the returns to scale, Sraffa implicitly reconsidered the models à la Dmitriev-Bortkievicz, which depicted the system of production and consumption as a circular process, emphasizing their «striking contrast to the view presented by modern theory, of a one-way avenue that leads from 'Factors of production' to 'Consumption goods'» (Sraffa 1960, p. 93). From this perspective, those interpretations of Production of Commodities which consider the schema of the book a Walrasian semi-general economic equilibrium in which prices are independent of demand, as in the Non-Substitution Theorem (see Samuelson 1987), seem unable to grasp the purpose of Sraffa's research programme and his theoretical originality.

\section{4. - CONCLUDING REMARKS}

The classical-Ricardian approach to the theory of prices developed by Ladislaus von Bortkievicz, who was the leading figure of the Russian-German mathe-

13 Sraffa wrote in the preface to Production of commodities: «It is .. a peculiar feature of the set of propositions now published that, although they do not enter into any discussion of the marginal theory of value and distribution, they have nevertheless been designed to serve as a basis for a critique of that theory» (p. vi). 
matical school of political economy, represents one of the most interesting achievements of the theoretical economic debate in Europe between the 1890's and the 1920 's. Two issues were paramount: the defence of the classical approach against Walras' and Böhm-Bawerk's criticisms, and the possible synthesis between classical and marginal theories of value. Bortkievicz, along the basis laid by Dmitriev, succeeded in reformulating the problem of price determination in Ricardo and Marx. In Dmitriev and Bortkievicz's works the classical revival appears to have been an attempt to correctly re-elaborate the theory of the cost of production using the mathematical method to show that price can be reduced to «elements independent of the subjective aspect of economic calculus» (ibid.). Renouncing what they considered the metaphysical investigation of the 'absolute value' problem, which had occupied Ricardo and Marx, Bortkievicz extracted the mathematical core of the classical theory of the cost of production, elaborating a scheme of production of commodities by means of commodities (or dated labour), in which the old theory of labour value represented only a particular case. Ricardo and Marx, in their theories of price formation, «held firmly to the view that the elements concerned must be regarded as a kind of casual chain, in which each link is determined, in its composition and its magnitude, only by the preceding links », Bortkievicz wrote (Bortkievicz 1907, p. 257) and called this trait of the Marxian system successivism, recalling Marshall's writings on Ricardo:

\footnotetext{
Modern economics is beginning to free itself gradually from the successivist prejudice, the chief merit being due to the mathematical school led by Léon Walras. The mathematical, in particular the algebraic method of exposition clearly appears to be the satisfactory expression for this superior standpoint, which does justice to the special character of economic relations (ibid. p. 257)
}

In a footnote, Bortkievicz added: «the dispute between the followers of the theory of costs of production and those of the theory of marginal utility is mainly a result of the successivist prejudice» (ibid. p. 289) - a thesis confirmed in his 1922 essay - which referred to Cassel (1899), who sustained a similar position. It is evident then that an organic synthesis of classical and marginal theories of value, based on the new methodology, was a programme common to many economists at that time.

In the thirties this programme broke up and split into different paths: one such path may be seen in the program of reconstruction of the general economic equilibrium theory developed in Vienna by Schlesinger, Wald and Von Neumann; another may be found in Leontiev's input-output line of research; and finally, there is the one which leads to Piero Sraffa's anti-marginalist research programme. It was certainly Sraffa who offered a model which was analytically and conceptually very close to Dmitriev's and Bortkievicz's ones: although the Italian economist did not simply stressed the logical consistency of the classical approach, but also tried to demonstrate that it could be a general theory, alternative to marginal theory, it seems reasonable to individuate the theoretical genesis of Sraffa's 1960 book in the intellectual background reflected by Bortkievicz and the Russian-German mathematical school of political economy. 


\section{REFERENCES}

O. Anderson, Ladislaus v. Bortkievicz, «Zeitschrift für Nationalökonomie », 1932, pp. 242-250.

O. Bauer, Marx-Literature (Review of Charasoff, 1910), «Der Kampf», 5, February 1905, pp. 237 238.

W.J. Baumol \& S.M. Goldfeld., eds., Precursors in Mathematical Economics, 1968, London School of Economics, London.

N. Bellanca, Economia politica e marxismo in Italia, Unicopli, Bologna, 1997.

H.G.W. Begehr et al., Mathematics in Berlin, Birkhäuser Verlag, Berlin, 1998.

E. Böhm-Bawerk, Zum Abschluss des Marxschen System, in O.v. Boenigk, Staaiswissenschaftliche Arbeiten. Festgabe für Karl Knies, Berlin, 1896. (English translation: Karl Marx and the Close of his System, A.M. MacDonald trans., T. Fisher Unwin, London, 1898; now in R. Marchionatti (ed.), Karl Marx. Critical Responses, Routledge, London, 1998, vol. II, pp. 172-242).

L. v. Bortkievicz, Review to Léon Walras, Eléments d'économie politique pure, «Revue d'Economie Politique», 4, 1890, pp. 80-86.

L. v. Bortkievicz, Die Grenznutzentheorie als Grundlage einer ultraliberalen Wirtschaftspolitik, in «Scholler Jahrbuch», vol. 22, 1898, pp. 1177-1216.

L. v. Bortkievicz, Wertrechnung und Preisrechnung im Marxschen System, «Archiv für Sozialwissenschaft und Sozialpolitik», 1906 (now in R. Marchionatti ed. Karl Marx. Critical Responses, cit. vol. III, pp. 199-237).

L. v. Bortkievicz, Wertrechnung und Preisrechnung im Marxschen System, «Archiv für Sozialwissenschaft und Sozialpolitik», 1907 (English Translation: Value an Price in the Marxian System, J. Kahane trans, in «International Economic Papers », 2, 1952 (now in R. Marchionatti ed. Karl Marx. Critical Responses, cit. vol. III, pp. 238-299).

L. v. Bortkievicz, Zur Berichtigung der Grundlegenden Theoretischen Konstruction von Marx im Dritten Band des Kapital, «Jahrbucher fur Nationalokonomie und Statistik», 1907b (English translation: On the Correction of Marx's Fundamental Theoretical Construction in the Third Volume of Capital, in P. M. Sweezy ed., Karl Marx and the Close of his System, New York, A.M. Kelley, 1949; now in R. Marchionatti ed. Karl Marx. Critical Responses, cit. vol. III, pp. 300318).

L. v. Bortkievicz, Obiektivismus und Subjektivismus in der Werttheorie, in Nationalekonomiska Studier till Knut Wicksell, Stockholm, 1921.

L. v. Bortkievicz, Dmitriev, Vladimir Karpovich, in Encyclopaedia of the Social Sciences, Macmillan, London \& New York, 1931.

E. Bouvier, La méthode mathématique en économie politique, in «Revue d'Economie Politique». 15, 1912, pp. 939-1086.

G. Cassel, Grundriss einer elementaren Preislehre, «Tübingen Zeitschrift», 60, 1899, pp. 395-458.

G. Charasoff, Karl Marx über die menschliche und kapitalistische Wirtschaft, H. Bondy, Berlin, 1909.

G. Charasoff, Das System des Marxismus : Darstellung und Kritik, H. Bondy, Berlin,1910.

V.K. Dmitriev, Ekonomicheskie Ocherki, Moscow, 1904 (English Translation: Economic Essays on Value, Competition and Utility, edited by D. M. Nuti. Cambridge University Press, Cambridge, 1974.

J. Eatwell \& C. Panico, Sraffa Piero (1898-1983), in The New Palgrave: A Dictionary of Economics, eds. J. Eatwell, M. Milgate \& P. Newman, Macmillan, London, 1987, pp. 445-451.

M. Egidi, Charasoff, George von, in The Elgar Companion to Classical Economics, eds. H.D. Kurz \& N. Salvadori, Elgar 1998.

M. Egidi \& G. Gilibert , La teoria oggettiva dei prezzi, «Economia Politica», April, 1984, pp. 43-61.

P. Garegnani, Il capitale nelle teorie della distribuzione, Giuffré, Milan, 1960.

P. Garegnani, Value and distribution in the classical economists and Marx, "Oxford Economic Papers », 36, 2, 1984, pp. 291-325. 
C. Gehrke, V.K. Dmitriev, in The Elgar Companion to Classical Economics, eds. H.D. Kurz \& N. Salvadori, Elgar 1998.

G. Gilibert, La scuola russo-tedesca di economia matematica e la dottrina del flusso circolare, in G. Becattini, ed.. Il pensiero economico : temi, problemi e scuole, UTET, Torino, 1990.

M.C. Howard \& J.E. King, L.v. Bortkievicz, in The Elgar Companion to Classical Economics, eds. H.D. Kurz \& N. Salvadori, Elgar 1998.

W. Jaffé, ed., Correspondence of Léon Walras and Related Papers, 3 vols. North-Holland, Amsterdam, 1965.

J.M. Keynes Wilhelm Lexis, «The Economic Journal », September, 1914 (Now in J.M. Keynes, Essays in Biography, vol. X, The Collected Writings of Keynes, The Royal Economic Society, London, 1972)

H.D. Kurz, Marginalism, Classicism and Socialism in German-Speaking Countries, 1871-1932, in I. Steedman, ed. Socialism and Marginalism in Economics, 1995, cit.

H.D. Kurz \& N. Salvadori, Von Neumann's growth model and the 'classical' tradition, in «The European Journal of the History of Economic Thought», Autumn, 1993, pp. 129-159.

H.D. Kurz \& N. Salvadori, eds. The Elgar Companion to Classical Economics, Elgar,1998.

R.J. Leonard, From Parlor Games to Social Science : von Neumann, Morgenstern, and the Creation of Game Theory 1928-1944, « Journal of Economic Literature», 33, 1995, pp. 730-761.

W. Leontiev, Die Wirtschaft als Kreislauf, «Archiv für Sozialwissenschaft und Sozialpolitik», 60, 1928, pp. 577-623 (English Translation: The Economy as a Circular Flow with an Introductory Note by W. Leontiev, in «Structural Change and Economic Dynamics», 2, 1991, pp. 180-212.

W. Lexis, Die Marx'sche Kapitaltheorie, in «Jahrbücher für Nationalökonomie und Statistik», 69, 1885, pp. 452-65.

W. Lexis, The Concluding Volume of Marx's Capital, «The Quarterly Journal of Economics », October, 1895, pp. 1-33.

A. Loria, I fondamenti scientifici della riforma economica, Bocca, Milano, 1922.

R. Marchionatti, Rilevanza e Limiti del Neoricardismo. Saggio su Dmitriev, Bortkievicz e Sraffa, Fe trinelli, Milano, 1981.

R. Marchionatti, ed. Introduction to Karl Marx: Critical Responses (R. Marchionatti ed.), Four Volumes, Routledge, London, 1998.

R. Marchionatti \& E. Gambino, Pareto and Political Economy as a Science: Methodological Revolution and Analytical Advances in Economic Theory in the 1890s, «Journal of Political Economy », 105, 6, 1997, pp. 1322-1348.

L. Meldolesi, Il contributo di Bortkievicz alla teoria del valore, della distribuzione e dell'origine del profitto, in L.v. Bortkievicz, La teoria economica di Marx (a cura di L. Meldolesi), Einaudi, Torino, 1971.

L. Meldolesi, Bortkievicz, Ladislaus von (1868-1931), in The New Palgrave: A Dictionary of Economics, edited by J. Eatwell, M. Milgate \& P. Newman, London, Macmillan, 1987, pp. 263-4.

C. Napoleoni, Valore, Milano, Isedi, 1976.

J. v. Neumann, Uber ein okonomisches Gleichungssystem und eine Verallgemeinerung des Browerschen Fixpunktsatze, in Ergebnisse eines mathematischen Kolloquiums, vol. 8, ed. Menger K. Leipzig, 1937 (English Translation: A model of general economic equilibrium, « Review of Economic Studies », 13, 1945, pp. 1-9).

A. Nove, Tugan-Baranovsky, Mikhail Ivanovich (1865-1919), in The New Palgrave: A Dictionary of Economics, cit., 1987, p. 705.

D.M. Nuti, Introduction to V.K. Dmitriev, Economic Essays, cit. 1974, pp. 7-28.

D. M. Nuti Dmitriev, Vladimir Karpovich (1868-1913), in The New Palgrave: A Dictionary of Economics, cit., 1987, pp. 907-910.

V. Pareto, Lettere a Maffeo Pantaleoni, 1890-1923, De Rosa G. editor, Roma, 1984.

R. Remak, Kann die Volkswirtschftslehre eine exacte Wissenschaft werden ?, «Jahrbücher für Nationalökonomie und Statistik», 131, 1929, pp. 703-735 (English Translation: A Postulated Price 
System in W.J. Baumol \& S.M. Goldfeld, eds. Precursors in Mathematical Economics, cit., pp. 271-277).

R. Remak, Konnen superponierte Preissysteme praktisch berechnet werden ?, « Jahrbücher für Nationalökonomie und Statistik», 138, 1933, pp. 839-842.

ARoncaglia, Sraffa and the Theory of Prices, Wiley, London, 1978.

P. Samuelson, Understanding the Marxian notion of exploitation: A summary of the so-called transformation problem between Marxian values and competitive prices, «Journal of Economic Literature », 9 (2), June 1971, pp. 339-431.

P. Samuelson, Sraffian economics, in The New Palgrave: A Dictionary of Economics, cit., 1987, pp.452-461..

P. Samuelson, Leontiev's 'The Economy as a Circular Flow' : An Introduction, « Structural Change and Economic Dynamics», 2, 1, 1991, pp. 11-179.

R. Scazzieri, Ziber on Ricardo, «Contributions to Political Economy », 6, 1987, pp. 25-44.

C. Schmidt, Der Dritte Band des Kapital, «Sozialpolitisches Zentralblatt», February, 1895, pp. 2558.

J.A. Schumpeter, History of Economic Analysis, Oxford University Press, New York, 1954.

J.A. Schumpeter, Ladislaus von Bortkievicz : 1868-1931, «The Economic Journal», 42, 1932, pp. 33840.

N.N. Shaposhnikov, Pervyi Russkii ekonomist-matematik Vladimir Karpovich Dmitriev, «Economiceskie Ocerki», 1914.

W. Sombart, Zur Kritik des ökonomischen Systems von Karl Marx, «Archiv für soziale Gesetzgebung », 15, 4, 1894, pp. 555-594.

P. Sraffa, Sulle relazioni tra costi e quantità prodotta, «Annali di Economia», II, 1925, pp. 277-328.

P. Sraffa, The laws of returns under competitive conditions, «The Economic Journal», 36, 1926, pp. 535-50.

P. Sraffa (ed)., The Work and Correspondence of David Ricardo, 11 vols., Cambridge University Press, Cambridge, 1951.

P. Sraffa, Production of Commodities by means of Commodities. Prelude to a critique of economic theory, Cambridge University Press, Cambridge, 1960.

I. Steedman ed., Socialism and Marginalism in Economics, 1870-1930, Routledge, London, 1995.

S. M. Stigler, The History of Statistics: The Measurement of Uncertainty before 1900, Harvard University Press, Cambridge Mass, 1986.

V.P. Timoshenko, Tugan Baranovsky and Western European Economic Thought. Speech on the $5^{\text {th }}$ Anniversary of His Death in «Annals of the Ukrainian Academy of Arts and Sciences in the United States », 1954, pp. 803-823.

M. Tugan-Baranowski, Theoretische Grundlagen des Marxismus, Dunker und Humblot, Leipzig, 1905.

S. Ulam, John von Neumann, 1903-1957, «Bulletin of the American Mathematical Society», 1958, pp. 1-8, and 41-2.

L. Walras, Eléments d'économie politique pure, ou Théorie de la richesse sociale, $4^{\text {th }}$ ed. Rouge, Lausanne, 1900. (English Translation Elements of Pure Economics, or, The Theory of Social Wealth, translated by W. Jaffé, Allen and Unwin, London, 1954).

W. Witmann, Die extremale Wirtschaft. Robert Remak ein Vorläufer der Aktivitätsanalyse, «Jahrbücher für Nationalökonomie und Statistik», 180, 1967, pp. 397-409.

W. Zawadzki, Les Mathématiques appliquées à l'économie politique, Rivière, Paris, 1914. 